\title{
Withering bicentennial celebrations
}

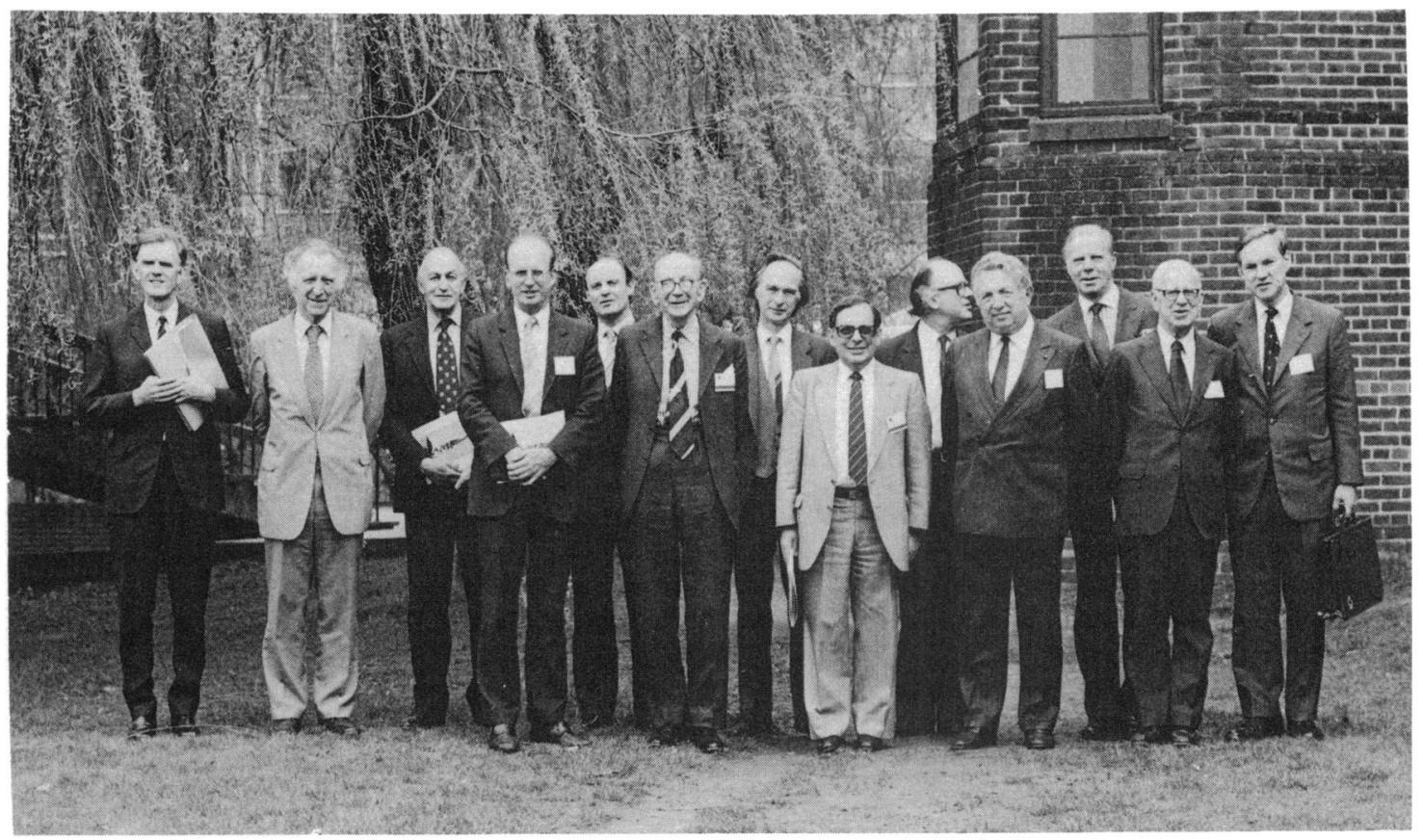

The chairman and speakers at the William Withering commemoration meeting, organised jointly by the Association of Physicians and British Cardiac Society, held on 18 April 1985.

From left to right: CT DOLLERY, SV PERRY, SIR RAYMOND HOFFENBERG, PRCP, DG GIBSON, W A LITTLER, SIR MELVILLE ARNOTT, D NOBLE, D M KRIKLER, A GUZ, F L MEIJLER, M F OLIVER, H B BURCHELL, and TW SMITH.

\section{British celebrations}

On 18 April 1985 the Association of Physicians of Great Britain and Ireland and the British Cardiac Society held a joint meeting in Birmingham to commemorate the two hundredth anniversary of the publication of William Withering's An Account of the Foxglove. The chairman of the meeting was Sir Raymond Hoffenberg, PRCP, William Withering Professor of Medicine at the University of Birmingham. The sessional chairmen were Michael Oliver, Sir Melville Arnott, and Howard Burchell, and Sir Raymond, who presided over the final scientific session, the William Withering Lecture of the Royal College of Physicians, given by Colin Dollery ( $p$ 234). Speakers in the scientific sessions were Thomas Smith, Denis Noble, Victor Perry, Dennis Krikler, William Littler, Frits Meijler, Abe Guz, and Derek Gibson; last minute indisposition prevented the participation of Charles Fisch. Abstracts of the papers appeared in the British Heart fournal 1985; 53: 686-7 but do not include the contributions of Littler, Meijler, Guz, and Gibson which were part of a debate under the chairmanship of Burchell. After the scientific proceedings, participants gathered at Edgbaston Parish Church, in whose yard Withering is buried, for an address by George Whitfield (p 253) and an orchestral recital. This was followed by a reception at Edgbaston Hall, Withering's old home, in whose grounds the foxglove still grows.

\section{American celebrations}

At its scientific sessions at Anaheim, the American College of Cardiology held a half-day meeting on 12 March 1985 to commemorate the publication of $A n$ 
Account of the Foxglove, with Charles Fisch as chairman and Dennis Krikler as co-chairman. Eugene Braunwald delivered the American College's William Withering Lecture entitled "Effects of cardiac glycosides on the contractility of the normal and failing heart". The papers presented at this meeting, together with other invited contributions, have been $\varsigma$ published as a supplement to the May 1985 issue of $\overrightarrow{\vec{B}}$ the fournal of the American College of Cardiology with Dr Fisch as guest editor. The flyleaf of the supplement is adorned by a colour photograph of Digitalis lanata by Frits Meijler. 